\author{
Tomasz KAŹMIERSKI ${ }^{1}$ \\ Karolina MAZURKIEWICZ ${ }^{2}$ \\ Tomasz SCHILLER ${ }^{3}$
}

\title{
WPŁYW UKŁADU SIECI WODOCIĄGOWEJ NA KOSZT TRANSPORTU ORAZ CZAS PRZEBYWANIA WODY W SIECI
}

\begin{abstract}
W pracy zbadano wpływ wyboru układu sieci wodociągowej na koszty tłoczenia oraz czas przebywania wody w systemie dystrybucji określony jej wiekiem. Wiek wody stanowi wskaźnik potencjalnych problemów z jej smakiem i zapachem - jego wydłużenie powoduje zazwyczaj pogorszenie jakości wody. W programie Epanet zbudowano kilkanaście różnych wariantów modelu systemu dystrybucji wody zasilającego gminę o liczbie mieszkańców ok. 10000 zlokalizowaną w Wielkopolsce. Część z nich stanowiły sieci o układzie scentralizowanym, w których wszyscy mieszkańcy byli zasilani z jednej stacji uzdatniania wody; pozostałe - o układzie zdecentralizowanym, w którym mieszkańcy gminy zasilani byli w wodę z kilku oddzielnych systemów dystrybucji wody. Poszczególne warianty różniły się między sobą m.in. średnicami przewodów wodociągowych, typem i ilością pomp oraz lokalizacją stacji uzdatniania wody i pompowni. Wszystkie warianty zostały zaprojektowane $\mathrm{z}$ uwzględnieniem spełnienia wymogów przeciwpożarowych. Dodatkowo minimalizowano zmiany ciśnienia wody w przewodach wodociągowych, gdyż zmienne warunki hydrauliczne, w tym gwałtowne zmiany ciśnienia są jedną z przyczyn wtórnego zanieczyszczenia wody w systemach jej dystrybucji. Po przeprowadzeniu symulacji komputerowych dokonano analizy dobowych kosztów tłoczenia wody oraz średniego ważonego wieku wody dla każdego wariantu. Na podstawie otrzymanych wyników wywnioskowano, że wy-bór rodzaju układu nie wpływa znacząco na dobowy koszt tłoczenia wody ani na wartość średniego ważonego wieku wody.
\end{abstract}

Słowa kluczowe: układ scentralizowany, układ zdecentralizowany, wiek wody, koszt tłoczenia wody

\footnotetext{
${ }^{1}$ Tomasz Kaźmierski, Politechnika Poznańska, Pl. M. Skłodowskiej-Curie 5, 60-965 Poznań, tomasz.kazmierski@put.poznan.pl

2 Autor do korespondencji / corresponding author: Karolina Mazurkiewicz, Politechnika Poznańska, Pl. M. Skłodowskiej-Curie 5, 60-965 Poznań, karolina.mazurkiewicz@put.poznan.pl

3 Tomasz Schiller, Politechnika Poznańska, Pl. M. Skłodowskiej-Curie 5, 60-965 Poznań, tomasz.schiller@put.poznan.pl
} 


\section{Wstęp}

\subsection{Wprowadzenie}

Głównym zadaniem systemu zaopatrzenia w wodę jest dostarczenie do odbiorcy wody o odpowiedniej jakości, w odpowiedniej ilości i pod odpowiednim ciśnieniem. Projektowanie systemów zaopatrzenia w wodę ma na celu spełnienie tych wymagań. Jednym z istotnych zagadnień jest wskazywanie wskaźników określających jakość wody w dowolnym punkcie sieci wodociągowej [7]. Jest to jednak zagadnienie skomplikowane, z uwagi na trafność ich wyboru, metodę modelowania lub oznaczania w systemie dystrybucji wody. Można jednak określić wskaźniki ogólne, nie identyfikujące specyficznych zagrożeń, lecz pozwalające ocenić możliwość pojawienia się potencjalnych trudności z utrzymanie jakości wody. Jednym z nich jest czas przebywania wody w sieci wodociągowej, tzw. wiek wody. Wraz z jego wzrostem jej jakość ulega zwykle pogorszeniu. Wiek wody jest wskaźnikiem potencjalnych problemów ze smakiem i zapachem [3], co zwykle jest skutkiem reakcji zachodzących w ramach zjawiska wtórnego zanieczyszczenia. Oprócz wieku wody w sieci wodociągowej występują również inne, powiązane z nim czynniki wpływające na jej wtórne zanieczyszczenie. Należą do nich m.in. brak stabilności chemicznej i biologicznej wody wprowadzanej do sieci wodociągowej, brak lub niewystarczające stężenie dezynfektanta w całym systemie dystrybucji wody, zły stan techniczny sieci, przyłączy i instalacji wewnętrznych, a także niewłaściwe i zmienne warunki hydrauliczne oraz gwałtowne zmiany ciśnienia w przewodach wodociągowych [6].

W piśmiennictwie przedmiotu zwraca się również uwagę na zużycie energii towarzyszące transportowi wody do odbiorcy [4]. Nadmierna energochłonność tłoczenia wody powinna zwracać uwagę projektantów oraz eksploatatorów systemów dystrybucji wody. Interesujące staje się dodanie do podanych wyżej głównych zadań systemu zaopatrzenia w wodę jeszcze jednego, równie istotnego - system dystrybucji powinien umożliwić transport wody przy racjonalnych nakładach energii.

W niniejszym artykule sprawdzono wpływ układu sieci wodociągowej na koszt transportu wody oraz jej wiek korzystając z wariantów modelu sieci wodociągowej o układzie scentralizowanym, w których wszyscy odbiorcy wody są zasilani z jednej stacji uzdatniania wody (SUW) i jednej sieci wodociągowej; oraz zdecentralizowanym, w których odbiorcy wody są zasilani z kilku SUW i osobnych sieci wodociągowych. Model sieci wodociągowej, przygotowany w programie Epanet [8], na podstawie którego wykonywano badania, odzwierciedla system dystrybucji wody dla gminy zlokalizowanej w Wielkopolsce o łącznej liczbie mieszkańców ok. 10 000. W każdym rozpatrywanym wariancie sieci wodociągowej zmieniano średnice przewodów, typ i ilość pomp oraz lokalizację SUW wraz z pompownią. Każdy z wariantów sprawdzano z uwzględnie- 
niem spełnienia wymogów przeciwpożarowych [11]. Dzięki przeprowadzonym symulacjom porównano wpływ zmian w systemie dystrybucji na koszt tłoczenia wody oraz jej wiek.

\subsection{Opis wielkości wybranych do porównywania wyników modelowania}

Analiza wyników modelowania sieci wodociągowych bazowała na niżej wymienionych wielkościach:

- koszcie tłoczenia wody wynikającym z energochłonności układu, obliczanym na podstawie zużycia energii przez zastosowane pompy,

- średnim ważonym wieku wody.

Dobowy koszt tłoczenia wody $\left(\mathrm{K}_{\mathrm{t}}\right)$ obliczano z poniższego wzoru:

$$
\mathrm{K}_{\mathrm{t}}=\sum_{\mathrm{i}=1}^{\mathrm{n}}\left(\mathrm{P}_{\mathrm{i}} \cdot \mathrm{t}_{\mathrm{i}}\right) \cdot \mathrm{k}
$$

gdzie: $\mathrm{P}_{\mathrm{i}}-$ moc zużywana przez poszczególne zastosowane pompy, [kW];

$\mathrm{t}_{\mathrm{i}}$ - czas działania i-tej pompy, $[\mathrm{h}]$;

$\mathrm{n}$ - liczba pomp działających w modelu sieci wodociągowej, [szt.];

$\mathrm{k}$ - jednostkowy koszt energii elektrycznej, [zł/kWh].

W obliczeniach przyjęto jednostkowy koszt energii elektrycznej równy $0,54 \mathrm{zt} / \mathrm{kWh}$.

Średni ważony wiek wody (W) obliczano ze wzoru.:

$$
\mathrm{W}=\frac{\sum_{\mathrm{i}=1}^{\mathrm{n}}\left(\mathrm{W}_{\mathrm{i}} \cdot \mathrm{L}_{\mathrm{i}}\right)}{\mathrm{L}}
$$

gdzie: $\mathrm{W}_{\mathrm{i}}$ - wiek wody obliczony dla wszystkich przewodów o danej średnicy d, [h];

$\mathrm{L}_{\mathrm{i}}$ - długość wszystkich przewodów o danej średnicy d, [m];

L - suma długości wszystkich przewodów w modelu sieci wodociągowej, [m];

$\mathrm{n}$ - liczba średnic d przewodów zastosowanych w modelu sieci wodociągowej, [szt.].

Biorąc pod uwagę powyższe wielkości, dla rozpatrywanych wariantów modelu sieci wodociągowej, każdorazowo oceniano wpływ lokalizacji źródła zasilania oraz zmian struktury sieci na koszt eksploatacyjny wyliczany z ilości energii zużywanej na tłoczenie wody oraz na średni ważony wiek wody. 


\section{Analizowane modele sieci wodociągowej}

W programie Epanet przygotowano kilkanaście modeli sieci wodociągowej, z których w niniejszym artykule przedstawiono wybrane. Cztery z nich przedstawiają sieć wodociągową w układzie scentralizowanym, trzy - w układzie zdecentralizowanym. Sytuację wysokościową na terenie rozpatrywanej gminy wraz z przykładowym rozmieszczeniem jednego z wariantów sieci wodociągowej o układzie scentralizowanym pokazano na rysunku 1.
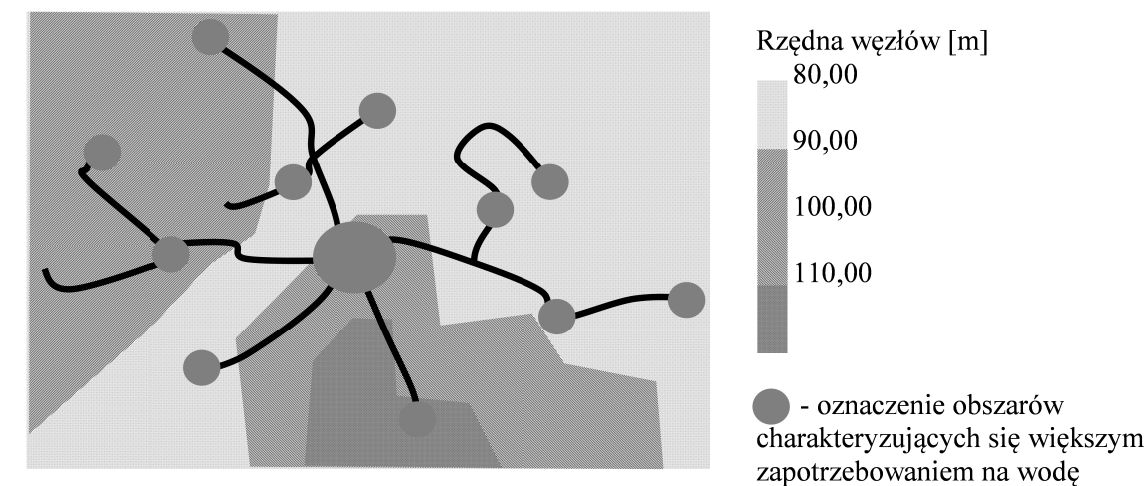

Rys. 1. Sytuacja wysokościowa na terenie systemu zaopatrzenia w wodę

Fig. 1. The situation of elevation in the water supply system

Poszczególne warianty sieci wodociągowych różniły się między sobą m.in. układem sieci, lokalizacją SUW i pompowni:

- wariant s1 stanowił układ scentralizowany ze SUW i pompownią II stopnia zlokalizowaną w samym centrum sieci (na terenie największych rozbiorów wody) (rys. 2),

- wariant s2 stanowił układ scentralizowany ze SUW i pompownią II stopnia zlokalizowaną w samym centrum sieci (na terenie największych rozbiorów wody); w porównaniu do wariantu s1 obniżono wysokość podnoszenia pompowni II stopnia i zaprojektowano pompownię III stopnia pomagającą zasilić w wodę tereny o najwyższych rzędnych,

- wariant s3 stanowił układ scentralizowany ze SUW zlokalizowaną na terenie o najwyższych rzędnych,

- wariant s4 stanowił układ scentralizowany ze SUW i pompownią II stopnia zlokalizowaną w centrum sieci (na terenie największych rozbiorốw wody), pompownią III stopnia zlokalizowaną na terenie o najwyższych rzędnych; w tym wariancie nastąpiła częściowa decentralizacji układu przez utworzenie dodatkowego źródła zasilania (rys. 3),

- wariant z1 stanowił układ zdecentralizowany - zaprojektowano cztery oddzielne systemy dystrybucji wody (rys. 4), 
- wariant z2 stanowił układ zdecentralizowany - zaprojektowano cztery oddzielne systemy dystrybucji wody; w porównaniu do wariantu z1, w systemie dystrybucji wody zlokalizowanym w południowej części gminy, SUW wraz z pompownią drugiego stopnia przeniesiono na teren o najwyższych rzędnych;

- wariant z3 stanowił zmodyfikowany wariant z2 z otwartym nowoprojektowanym przewodem (utworzenie pierścienia sieci wodociągowej) (rys. 4).

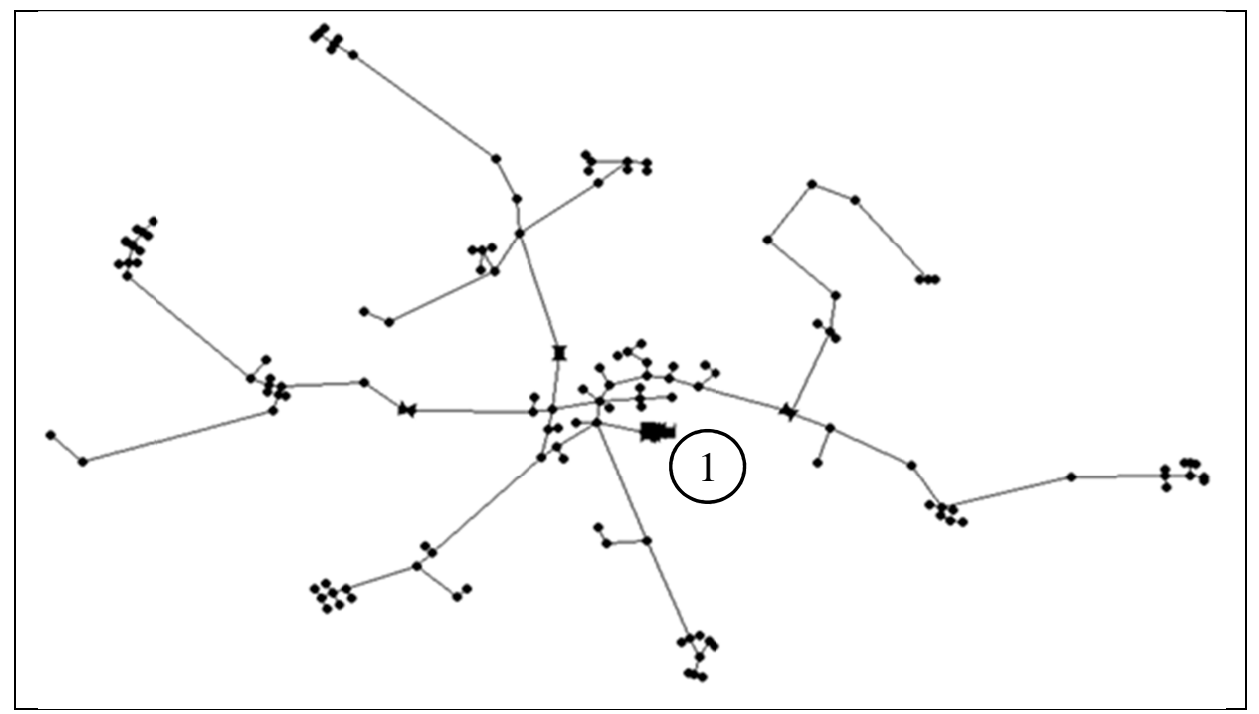

Rys. 2. Struktura sieci wodociągowej - wariant s1 - SUW oraz pompownia drugiego stopnia zlokalizowana w punkcie 1

Fig. 2. The water supply system - s1 variant- water treatment plant and $\mathrm{II}^{\circ}$ pump station at point 1

Poszczególne warianty charakteryzowały się średnicami wewnętrznymi przewodów pokazanymi w tabeli 1 . We wszystkich wariantach przyjęto współczynnik chropowatości bezwzględnej równy $0,05 \mathrm{~mm}$.

Położenie oraz wielkość poszczególnych odbiorców wody, a także uwzględnienie wymogów Rozporządzenia [11] i potraktowanie sieci jako źródła wody także na cele przeciwpożarowe, spowodowało iż od 31,1 do $70,4 \%$ przewodów w poszczególnych wariantach charakteryzowało się średnicą wewnętrzną 96,8 mm (tab. 1). Gdyby przyjąć założenie, że można zastosować inne źródła zasilania w wodę do gaszenia pożarów (na przykład zbiorniki naturalne lub sztuczne), to graniczna minimalna średnica przewodu mogłaby zostać zmniejszona. 


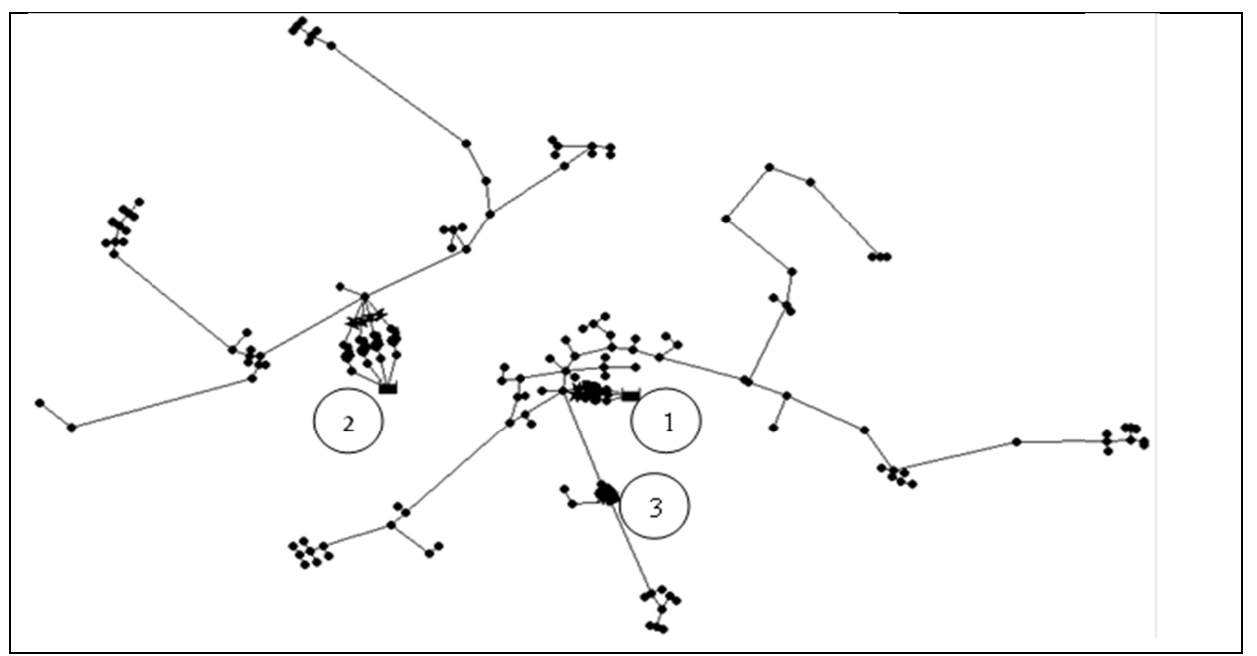

Rys. 3. Struktura sieci wodociągowej - wariant s4 - częściowa decentralizacja systemu dystrybucji wody (SUW oraz pompownia drugiego stopnia zlokalizowana w pkt.1 i 2, pompownia trzeciego stopnia w pkt. 3)

Fig. 3. The water supply system - s4 variant - partial decentralization (water treatment plant and II $^{\circ}$ pump station at point 1 and $2, \mathrm{III}^{\circ}$ pump station at point 3 )

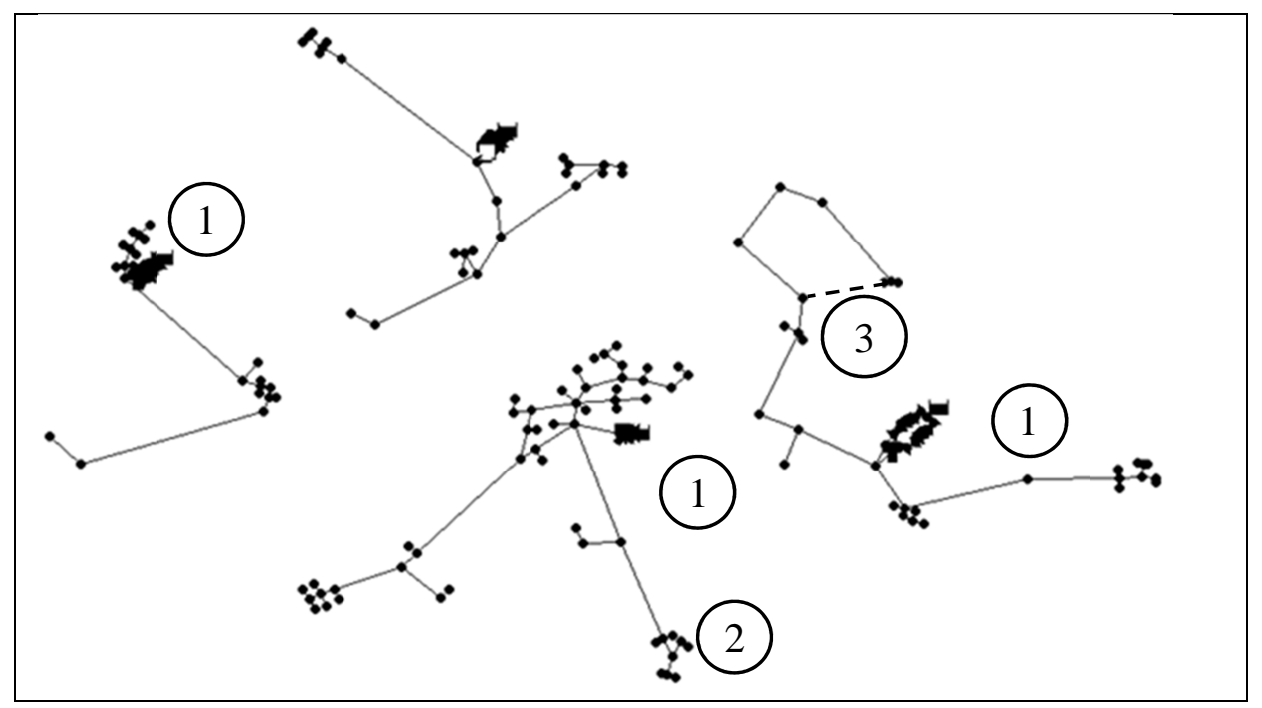

Rys. 4. Struktura sieci wodociągowej - wariant z1 i z3 - SUW oraz pompownie drugiego stopnia zlokalizowane w pkt. 1, w wariancie z3 SUW oraz pompownie drugiego stopnia zlokalizowane w pkt. 2 oraz dodano nowoprojektowany przewód wodociągowy w pkt. 3

Fig. 4. The water supply system - z1 and z3 variant - water treatment plants and $\mathrm{II}^{\circ}$ pump stations at points 1 , in the $3^{\text {rd }}$ variant water treatment plant and II $^{\circ}$ pump station at point 2 , new projected pipe at point 3 
Ilość i średnica zastosowanych w poszczególnych wariantach przewodów miała na celu znalezienia rozwiązania racjonalnego z punktu widzenia czasu przebywania w sieci i kosztu transportu wody. Wymienione wyżej uwarunkowania powodują jednak, że modelowane prędkości przepływu w większości przewodów są rzędu $0,05-0,08 \mathrm{~m} / \mathrm{s}$.

Tabela 1. Procentowy udział przewodów o danej średnicy w stosunku do długości całej sieci w poszczególnych jej wariantach Długości rur o danej średnicy zastosowane w poszczególnych wariantach

Table 1. Percentage of pipe of a given diameter with the length of the entire network in each of its variants

\begin{tabular}{|c|c|c|c|c|c|c|c|}
\hline $\begin{array}{c}\text { Udział przewodów } \\
\text { o danej średnicy [\%] }\end{array}$ & \multicolumn{7}{|c|}{ Wariant } \\
\hline Średnica [mm] & S1 & S2 & S3 & S4 & Z1 & $\mathbf{Z 2}$ & $\mathbf{Z 3}$ \\
\hline 96,8 & 39,7 & 68,0 & 37,3 & 70,4 & 31,1 & 31,1 & 31,1 \\
\hline 110,2 & 22,5 & - & 15,4 & - & 35,1 & 35,1 & 35,1 \\
\hline 123,3 & 3,7 & - & 15,0 & - & 10,2 & 9,6 & 9,6 \\
\hline 141,0 & 11,8 & 12,2 & 12,3 & 8,5 & 23,3 & 17,0 & 17,0 \\
\hline 158,6 & 12,2 & 12,6 & 12,2 & 13,4 & - & 3,5 & - \\
\hline 176,2 & - & - & - & - & 0,2 & 3,6 & - \\
\hline 198,2 & 4,1 & 7,2 & 1,8 & 7,7 & - & - & 6,8 \\
\hline 220,4 & 5,8 & - & 0,1 & - & - & - & 0,2 \\
\hline 277,6 & - & - & 5,7 & - & - & - & - \\
\hline 312,8 & 0,2 & - & 0,2 & - & - & - & - \\
\hline Suma & 100,0 & 100,0 & 100,0 & 100,0 & 100,0 & 100,0 & 100,0 \\
\hline
\end{tabular}

Uwaga. Znak ,-,, wskazuje na brak średnicy przewodu w danym wariancie sieci.

\section{Wyniki symulacji komputerowych}

$\mathrm{Na}$ przygotowanych modelach sieci przeprowadzono symulacje działania systemów dystrybucji wody. Uzyskane wyniki podsumowano wykresami na rysunkach 5 i 6.

Na podstawie wyników modelowania obliczano wartość ilorazu ciśnienia wody w węźle będącego wynikiem symulacji działania danego modelu sieci do wymaganej wartości ciśnienia w węźle dla poprawnego pobierania wody przyjętej jako $30 \mathrm{~m}$. Zmiany ciśnienia wody w przewodach wodociągowych przekładają się na zmiany wartości tego ilorazu. Zmienne warunki hydrauliczne, w tym gwałtowne zmiany ciśnienia są jedną z przyczyn wtórnego zanieczyszczenia 
wody w systemach dystrybucji wody [6, 9]. Z uwagi na jakość wody pracę pomp projektowano w taki sposób, by minimalizować wahania ciśnienia.

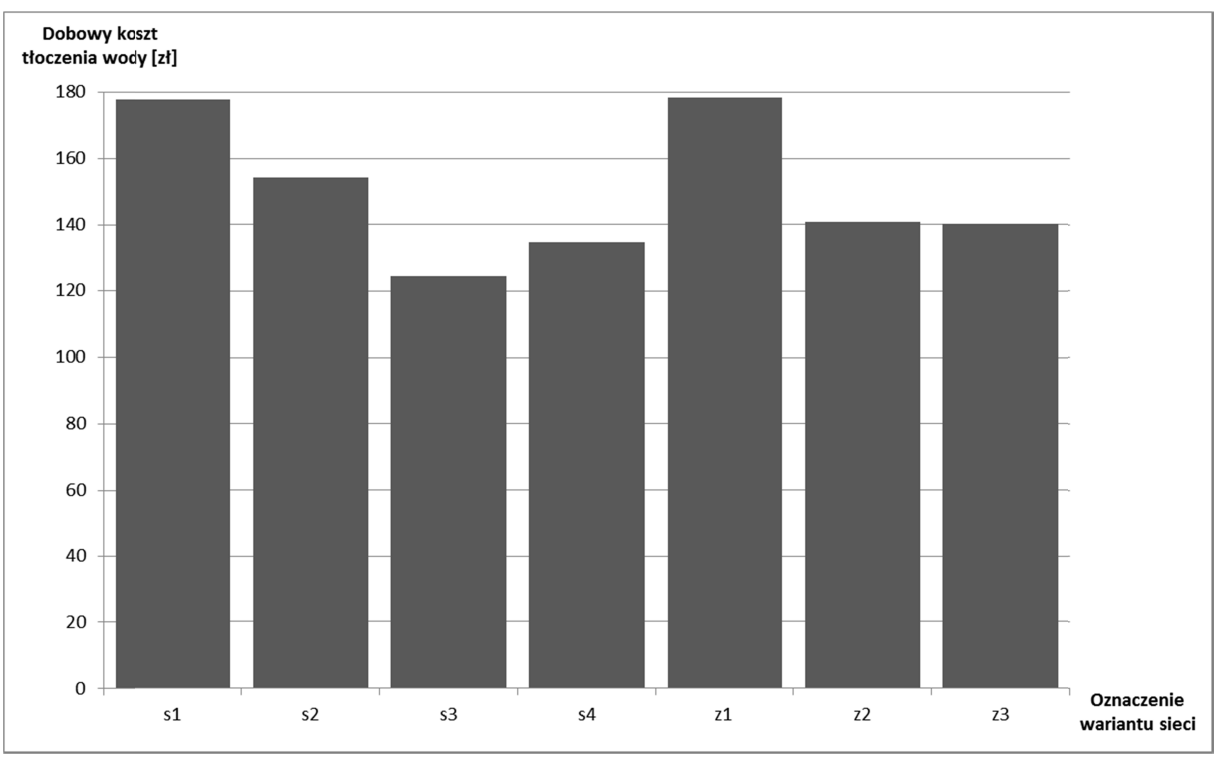

Rys. 5. Zestawienie dobowych kosztów tłoczenia wody dla poszczególnych wariantów

Fig. 5. Daily pumping costs for individual variants

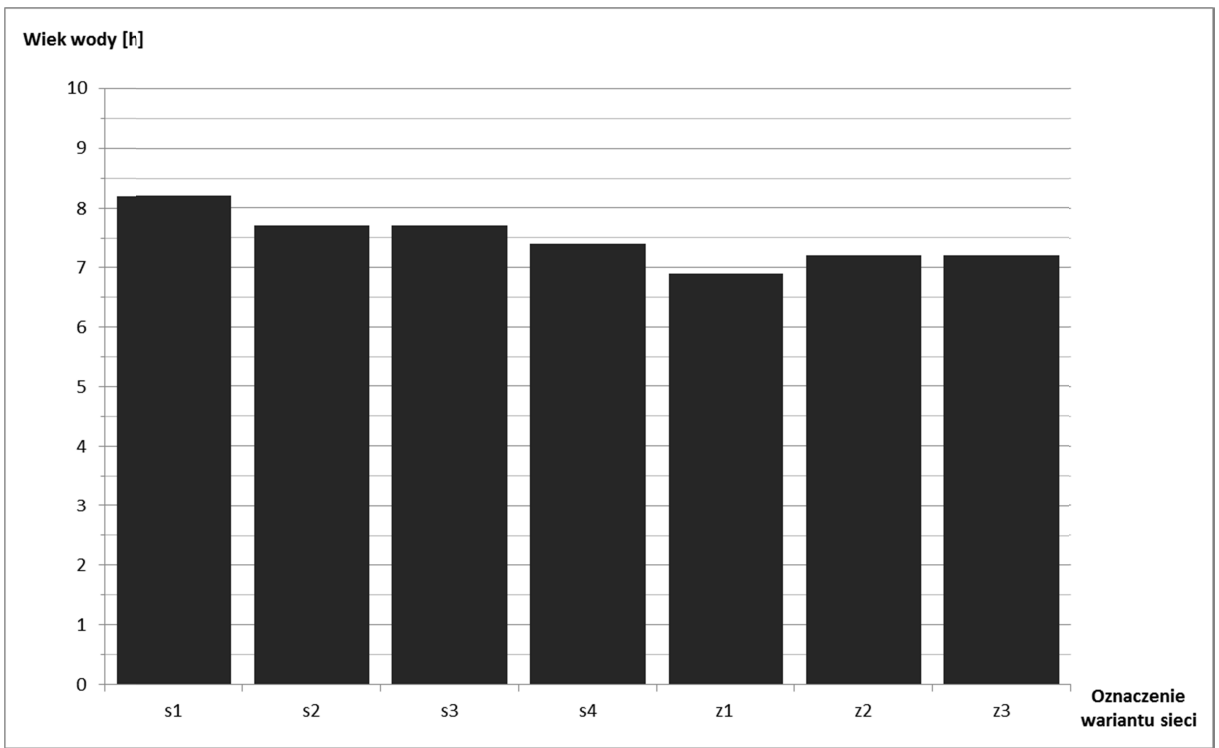

Rys. 6. Zestawienie średnich ważonych wartości wieku wody dla poszczególnych wariantów

Fig. 6. Weighted average water ages for individual variants 
Na rysunku 5 pokazano zestawienie dobowych kosztów tłoczenia wody w zależności od wariantu. Najwyższe dobowe koszty tłoczenia wody wynoszące niemal 180 zł/d uzyskano dla wariantów s1 i z1. Najniższy dobowy koszt tłoczenia wody (ok. $125 \mathrm{zt} / \mathrm{d}$ ) uzyskano dla wariantu s3.

Dobowy koszt tłoczenia wody dla wariantu s1 jest porównywalny z z1. Wynika to z lokalizacji SUW wraz z pompownią II stopnia na terenie o największych rozbiorach i wymaganej wówczas większej wysokości podnoszenia zainstalowanych tam pomp, by możliwe było zasilenie w wodę południowej część gminy, która jest położona wyżej w stosunku do rzędnych SUW.

Pozostałe dobowe koszty tłoczenia wody są również na porównywalnym ze sobą poziomie. Koszty tłoczenia wody dla obu układów - scentralizowanego i zdecentralizowanego - zależą od zastosowanego wariantu lokalizacji pompowni II stopnia, a co za tym idzie - od wymaganej wysokości podnoszenia pomp.

Rysunek 6 przedstawia zestawienie średnich ważonych wartości wieku wody. Obliczone wartości średniego ważonego wieku wody dla każdego wariantu były porównywalne: najwyższą wartość wynoszącą $8,2 \mathrm{~h}$ otrzymano dla wariantu s1, najniższą - wynoszącą $6,9 \mathrm{~h}$ dla wariantu z1.

\section{Podsumowanie i wnioski}

Zmiana układu sieci wodociągowej (jej decentralizacja) nie zmniejsza znacząco czasu przebywania wody w sieci. Jego średnia ważona wartość zmienia się od 6,9 h do $8,2 \mathrm{~h}$ w zależności od wariantu sieci. W przypadku małych sieci wodociągowych występuje niekorzystna czasowa struktura poboru wody, powodująca jej stagnację w przewodach wodociągowych [5]. Dodatkowo wymagane dla celów przeciwpożarowych minimalne średnice przewodów są czasem przewymiarowane w przypadku niewielkiej liczby odbiorców wody, co również jest powodem niewielkich prędkości przepływu wody osiąganych w przewodach, szczególnie w małych jednostkach osadniczych. Te czynniki są również powodem niewielkiego zmniejszenia średniego ważonego wieku wody w przypadku zastosowania układu zdecentralizowanego (rozbicie sieci wodociągowej na kilka mniejszych). Na przykładzie modelowanej sieci wodociągowej i jej modyfikacji można stwierdzić, że tam gdzie pozwalają na to przepisy [11], należy stosować alternatywne źródła wody na cele przeciwpożarowe. Otrzymane wyniki pokazują bowiem, że uzyskanie znaczącej zmiany wieku wody, jako parametru wskazującego na potencjalne problemy z jej jakością, nie jest możliwe bez zwiększenia prędkości przepływu wody (zmniejszenia średnic) lub zastosowania innych rozwiązań $[1,2]$ pozwalających na dostarczenie odbiorcy wody w odpowiedniej ilości, pod odpowiednim ciśnieniem i o jakości wynikających z obowiązujących rozporządzeń.

Koszt tłoczenia wody zmieniał się od około $125 \mathrm{zł} / \mathrm{d}$ do około $180 \mathrm{zł} / \mathrm{d}$ w zależności od wariantu sieci. Należy zaznaczyć, że w większości przypadków sprawność pompowania wody można uznać za dobrą [10]. Największy dobowy 
koszt tłoczenia wody uzyskano dla wariantów, w których SUW wraz z pompownią II stopnia były zlokalizowane na terenie największych rozbiorów i konieczne było zwiększenie wysokości podnoszenia zainstalowanych tam pomp, by umożliwić zasilenie $w$ wodę terenów położonych najwyżej, tj. południowej części gminy. Podniesie wysokości podnoszenia pomp, wynikające $\mathrm{z}$ niekorzystnego układu wysokościowego, wpłynęło w znaczący sposób na wzrost kosztów tłoczenia wody.

Na podstawie otrzymanych wyników można wywnioskować, że proponowane zmiany w systemie dystrybucji wody (wybór pomiędzy układem scentralizowanym a zdecentralizowanym) nie wpływają znacząco na dobowy koszt tłoczenia wody ani na wartość średniego ważonego wieku wody. Wyniki badań potwierdziły natomiast, że ważnym czynnikiem wpływającym na dobowy koszt tłoczenia wody jest lokalizacja pompowni, która pozwoli uniknąć zwiększenia wysokości podnoszenia zainstalowanych na niej pomp celem zasilenia w wodę wszystkich odbiorców.

Wzajemne rozmieszczenie źródeł i odbiorców wody może spowodować, że zastosowanie decentralizacji systemu nie przyniesie oczekiwanych efektów w postaci na przykład zmniejszenia wieku wody. Może to wynikać choćby ze struktury istniejącego systemu dróg lub podziału własności ziemi, na której lokalizowany jest system dystrybucji wody. W tabeli 2 pokazano odległość najdalej wysuniętych punktów poboru wody od SUW przed i po decentralizacji.

Tabela 2. Odległość najdalej wysuniętych punktów poboru wody od SUW

Table 2. The distance between the water treatment plant and the furthest points of water demand

\begin{tabular}{|c|c|c|}
\hline \multirow{2}{*}{$\begin{array}{c}\text { Układ } \\
\text { sieci wodociągowej }\end{array}$} & \multicolumn{2}{|c|}{$\begin{array}{c}\text { Odległość najdalej wysuniętego punktu systemu } \\
\text { od SUW }\end{array}$} \\
\cline { 2 - 3 } & $\begin{array}{c}\text { mierzona w linii prostej } \\
{[\mathbf{m}]}\end{array}$ & $\begin{array}{c}\text { mierzona wzdłuż trasy } \\
\text { przewodu [m] }\end{array}$ \\
\hline scentralizowany & 4200 & 9700 \\
\hline decentralizowany & 2600 & 8200 \\
\hline
\end{tabular}

Jak pokazano w tabeli 2 decentralizacja sieci wodociągowej skróciła odległość najdalej położonego punktu poboru wody od SUW mierzoną w linii prostej. Konieczność lokalizowania przewodów wzdłuż istniejącej siatki dróg spowodowała jednak, że decentralizacja nie skróciła znacząco trasy, jaką woda musi przebyć od SUW do odbiorcy. 


\section{Literatura}

[1] Bromberek Z., Kaźmierski T., Mazurkiewicz K., Mróz T., Schiller T.: Zarządzanie zasobami wodnymi $\mathrm{w}$ przestrzeni zurbanizowanej jako narzędzie planowania zrównoważonego rozwoju jednostek osadniczych, IV Międzynarodowa Konferencja Naukowo-Techniczna INFRAEKO 2014, 29-30 maja 2014 r.

[2] Bromberek Z., Kaźmierski T., Mazurkiewicz K., Mróz T., Schiller T.: Metoda planowania zabudowy zrównoważonej w oparciu o racjonalną infrastrukturę techniczną, IV Międzynarodowa Konferencja Naukowo-Techniczna INFRAEKO 2014, 29-30 maja $2014 \mathrm{r}$.

[3] Elton A., Brammer L.F.,Tansley N.S.: Water quality modeling in distribution networks, Journal AWWA, Vol. 87, No. 7, 1995, pp. 44-52.

[4] Jędral W.: Efektywność energetyczna pomp i instalacji pompowych, Krajowa Agencja Poszanowania Energii, Warszawa 2007.

[5] Kłos M., Zimoch I.: Wykorzystanie analizy jakości wody do oceny pracy sieci wodociągowej, Ochrona Środowiska 2005, Rok 27, Nr 4, s. 27-30.

[6] Kowal A.L., Świderska-Bróż M.: Oczyszczanie wody. Podstawy teoretyczne i technologiczne, procesy i urządzenia, Wydawnictwo Naukowe PWN, Warszawa 2009.

[7] Reddy L.S., Ormsbee L.E., Wood D.J.: Time-Averaging Water Quality Assessment, Journal AWWA, Vol. 87, No. 7, 1995, pp. 64-73.

[8] Rossman L.A.: Epanet. Users manual, United States Environmental Protection Agency, Cincinnati 2000.

[9] Tatara M.: Wtórne zanieczyszczenia wody wodociągowej podczas jej dystrybucji w aspekcie pogorszenia fizykochemicznej jakości wody, GWiTS, 6/2001, s. 201-205.

[10] Wowk J.: Ocena energetyczna pompowni, Pompy Pompownie 4/2011.

[11] Dz.U. 2009 nr 124 poz. 1030: Rozporządzenie Ministra Spraw Wewnętrznych i Administracji z dnia 24 lipca 2009 r. w sprawie przeciwpożarowego zaopatrzenia w wodę oraz dróg pożarowych.

\section{THE INFLUENCE OF THE WATER SUPPLY SYSTEM DESIGN ON WATER TRANSPORT COST AND TIME IN WHICH WATER STANDS IN THE NETWORK}

\section{S u m m a r y}

The purpose of analysis presented in the paper was to examine the influence of the layout of the water supply system on daily pumping costs and time of water remaining in the network evaluated as water age. Water age is an indicator of potential problems with water taste and odour. The increase in water age results usually in deterioration of water quality. With the use of Epanet application several different variants of a water supply system model has been built for a district of appx. 10000 inhabitants located in Wielkopolska. In some variants a centralized layout of network was used, in which all inhabitants were supplied from one water treatment plant, whereas in other variants the network layout was decentralized, i.e. inhabitants were supplied from separate water supply systems. Examined variants differed from each other with regard to the pipe diameter, pump type, quantity of pipe and localization of water treatment plant and pumping stations. All 
variants were designed to fulfill requirements of fire resistance standards. Additionally, the changes of water pressure inside network were minimized, because the rapid changes of water pressure can result in a secondary contamination of water in a water distribution system. On the basis of computer simulations, the analysis of daily pumping costs and average weighted water age was performed for each variant. The results of the analysis showed that the type of water supply system layout does not have a significant influence on daily pumping costs and average weighted water age.

Keywords: centralized water supply system, decentralized water supply system, water age, pumping cost

DOI: $10.7862 / \mathrm{rb} .2016 .158$

Przestano do redakcji: $01.05 .2016 r$.

Przyjęto do druku: 28.06.2016 r. 